\title{
Morphological and biomechanical study of abdominal aorta of rats submitted to experimental chronic alcoholism ${ }^{1}$
}

\author{
Avaliação morfológica e biomecânica da aorta abdominal de ratos submetidos ao \\ alcoolismo crônico experimental
}

\author{
Nereide Freire Cerqueira², Winston Bonetti Yoshida ${ }^{3}$, Sérgio Swain Müller ${ }^{4}$, Júlio Lopes Sequeira ${ }^{5}$, Antônio de Castro \\ Rodrigues $^{6}$, Carlos Roberto Padovani ${ }^{7}$
}

1. Article from School of Veterinary Medicine and Animal Science. UNESP - São Paulo State University. Botucatu.

2. Doctor of Veterinary Medicine, School of Veterinary Medicine and Animal Science. UNESP - São Paulo State University. Botucatu.

3. Associate Professor, Department of Surgery and Orthopedics. School of Medicine, UNESP - São Paulo State University. Botucatu.

4. Assistant Professor, Dept. of Surgery and Orthopedics, School of Medicine. UNESP - Botucatu.

5. Assistante Professor, Dept. of Clinical Veterinary, School of Veterinary Medicine and Animal Science. UNESP - Botucatu.

6. Associate Professor, Dept. of Biological Sciences, School of Odontology. USP. Bauru.

7. Chairman, Dept. of Bioestatistics, Institute of Biosciences. UNESP - Botucatu.

\begin{abstract}
Purpose: To assess the influence of experimental chronic alcoholism in the morphology and biomechanics of the aorta, in a rat model. Methods: Forty-four Wistar rats were randomly divided into two groups of 22 animals each: in the alcoholism group, the rats received water mixed to increasing concentrations of ethyl alcohol; and control group: the rats received pure water for 180 days. The animals were then killed by an overdose of pentobarbital and the abdominal aortas were excised for histological (hematoxylin-eosin, Masson, Calleja, and Picrosirius red stain), histomorphometrical, and biomechanical analysis. Results: Histology and histomorphometry did not show differences in aorta morphology of both groups. Biomechanical analysis showed a significantly greater yield point elongation in the alcoholic rat group ( $<<0.05$ ). Conclusion: Chronic alcoholism did not cause morphological alterations in the aortic wall but increased elongation, without modifying any other mechanical properties.
\end{abstract}

Key words: Alcoholism. Ethanol. Aorta. Elasticity.

\section{RESUMO}

Objetivo: avaliar a influência do alcoolismo crônico experimental na morfologia e biomecânica da artéria aorta de ratos. Metódos: ratos Wistar foram divididos em dois grupos de 22 animais. Grupo alcoolista: os ratos receberam água com concentração crescente de etanol e ração ad libitum durante 6 meses. Grupo controle: os animais receberam água e ração ad libitum pelo mesmo período. Os animais foram sacrificados com overdose de pentobarbital e as aortas abdominais foram excisadas para realização de histologia (hematoxilina-eosina, tricrômio de Masson, Calleja, Picrosirius red), histomorfometria e avaliação biomecânica (carga máxima, alongamento na carga máxima, limite de proporcionalidade, alongamento no limite de proporcionalidade e coeficiente de rigidez). Resultados: A histologia e a histomorfometria não mostraram diferenças significantes na morfologia da aorta em ambos os grupos. A avaliação biomecânica mostrou aumento do alongamento no limite de proporcionalidade no grupo alcoolista $(\mathrm{p}<0.05)$. Conclusão: 0 alcoolismo crônico experimental não provocou alterações morfológicas na parede da aorta, mas causou aumento da sua elasticidade, sem modificar as outras propriedades mecânicas avaliadas.

Descritores: Alcoolismo. Etanol. Aorta. Elasticidade.

\section{Introduction}

Alcoholism is a severe and widespread disease all over the world. Approximately $70 \%$ of adult Americans drink alcohol occasionally, and alcohol abuse affects 5 to $10 \%$ of men and 3 to $5 \%$ of women ${ }^{1}$. Alcohol has been experienced at least once by $69 \%$ of Brazilian people, being $77 \%$ men and $60 \%$ women $^{2}$. A study of psychiatric morbidity performed in three Brazilian cities (Brasília, São Paulo, and Porto Alegre) showed prevalence of alcohol abuse in $15.4 \%$ men and 1.2\% women ${ }^{3}$. In Brazil, alcoholism affects 12 million people, accounting for $90 \%$ of drug addiction hospitalizations ${ }^{4}$.

Chronic alcohol abuse is associated with increased morbidity and mortality and may cause morphological alterations in almost all body organs and tissues. Alterations in liver, nervous and cardiovascular systems, gastrointestinal tract, pancreas, skeletal muscle, and blood cell are frequent. Also, incidence of hypertension and certain cancers, as well as accidents and suicides increase with alcoholism $^{5,6,7}$. In contrast, epidemiological studies have associated moderate alcohol consumption with a reduced 
incidence of cardiovascular disease ${ }^{8}$. Alterations in chemical and structural properties of biological membranes are reported after ethanol addiction ${ }^{9,10}$. However, clinical significance of the adverse effects of alcohol on the arterial wall remains controversial. Some authors showed morphological changes in the arterial wall ${ }^{11,12,13}$, while others did not find any alteration ${ }^{14}$. So, the objective of the present study is to evaluate histopathology, histomorphometry, and mechanical properties of the abdominal aorta of rats submitted to chronic alcoholism. To our knowledge, biomechanical properties of blood vessels in alcoholic rats were not previously studied.

\section{Methods}

All procedures were performed in strict accordance to the guidelines of the U.S. National Research Council's "Guide for the care and use of laboratory animal" (NRC publication - 1996) and were approved by the local "Ethical Committee for Animal Research". Forty-four adult male Wistar rats weighing $302.9 \pm 14.1 \mathrm{~g}$ were used. The animals were randomly divided into 2 experimental groups of 22 animals each (control and alcoholic). Food and water were given ad libitum to the control group. The alcoholic animal group was fed with the same food, but received water with increasing concentrations of sugar cane ethanol (Pirassununga 51 - Müller Liquor Industry, Ltd. Piracicaba, SP, Brazil) ad libitum. The final ethanol concentrations in drinking water were $10^{\circ}$ in the first 7 days, $20^{\circ}$ in the following 7 days, and $30^{\circ}$ from the $14^{\text {th }}$ day to the end of the study, with 180 days of ethanol consumption.

The animals were kept in groups up to 5 rats per cage in a dry and airy place at steady and controlled temperature. Food and liquid intakes were recorded daily in each cage. Animal weight was determined weekly, always in morning time. At the end of the observation period, the animals were killed by an overdose of pentobarbital (HYPNOL ${ }^{\circledR} 3 \%$, Cristália, São Paulo, SP, Brazil) with the excision of the abdominal portion of aorta and liver.
Liver samples were fixed in 10\% formaldehyde and stained with hematoxylin-eosin (HE) and aortic histological examination was performed in 5 animals of each group chosen at random. Aortic samples were fixed in $10 \%$ formaldehyde and stained with HE, Masson, Calleja, and Picrosirius red. Aortic slides stained with Calleja were sent for histomorphometrical analysis using a LEICA DMLB microscope. Digital images were processed in an IBM personal computer using IPWIN32 software which was used to calculate the proportion of collagen in the tunica media and adventitia and the width of the media, adventitia, and media + adventitia.

Aortic mechanical properties were studied in the 17 control and 17 alcoholic remaining rats. Before biomechanical testing, the aortas were promptly immersed in saline solution containing $0.25 \mathrm{mg} / \mathrm{mL}$ of papaverine, to relax the muscle bundles of the arteries, and to standardize the state of muscle tension in all aortic samples ${ }^{15}$.

The biomechanical analysis was performed using a EMIC DL 10.000 Universal Machine of Mechanical Assays (Equipments and Testing Systems, Ltd. Curitiba, PR, Brazil). The aortas were immediately fixed with grasping clamps using smooth non-cutting metallic bars fastened with two screws. The stretching speed was $30 \mathrm{~mm} /$ minute and a $50 \mathrm{~N}$ load cell was used. Failure load, failure elongation, yield point by Johnson's method, yield point elongation, and stiffness were obtained ${ }^{16}$. Failure load may be defined as the highest load tolerated by materials until rupture. Yield point is the maximum tension value below which materials comply with Hooke's law (where tension-deformation function is linear). Beyond the yield point, some degree of lesion may be found and materials already present of plastic deformation, making the return to initial length impossible, even if loading stops. Failure elongation is the difference between length in the failure load region and initial length; yield point elongation is the difference between length in the yield point region and initial length. Stiffness is the linear and constant numeric relation between load and elongation calculated at the yield point (Figure 1$)^{16}$.

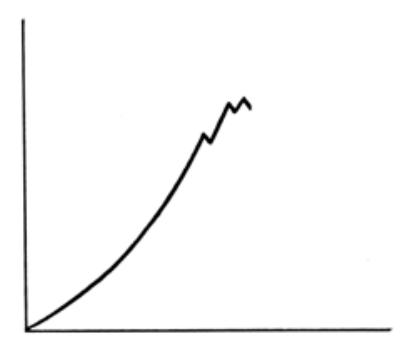

A

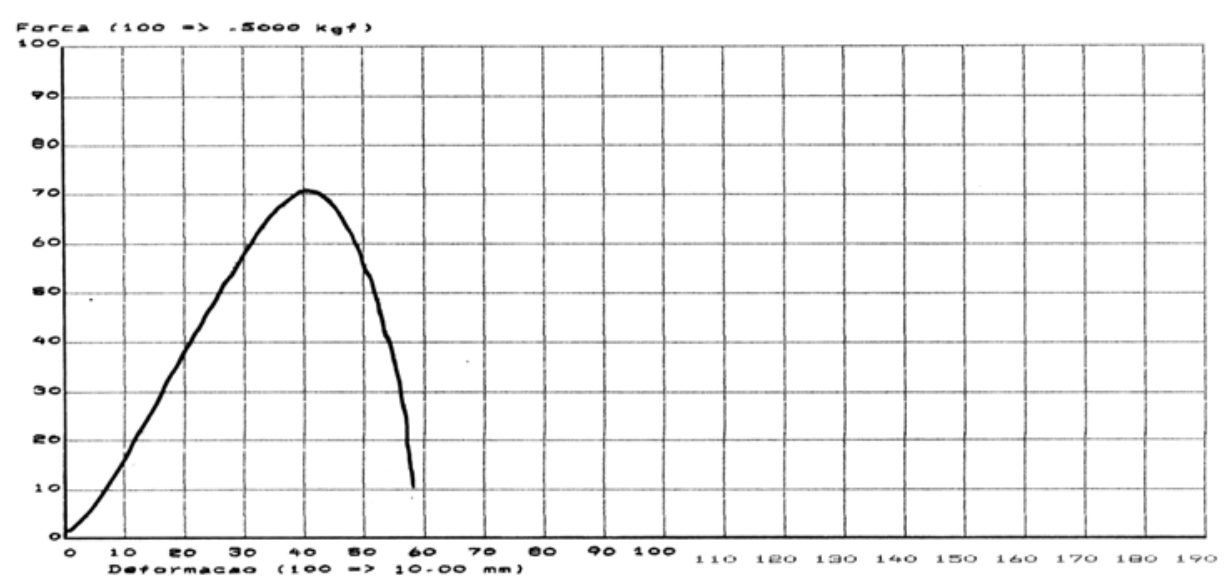

B

FIGURE 1 - A: Load-elongation diagram showing the various segments of the curve: 1) accommodation; 2) elastic phase, which higher point is called yield point; 3) plastic phase; and 4) rupture limit, which is the same of failure load (Adapted from Carlstedt \& Nordin, 198916) B: Loadelongation diagram of alcoholic group rat. 
The Student's t test (two independent samples) was used for the biomechanical results and width of the media and adventitia. The proportion of collagen in these tunicas was compared using the Mann-Withney test. Pearson's and Spearman's coefficient was used for the correlation between weight and biomechanical variables ${ }^{17}$. Mean body weight evolution of both groups along the experiment was compared using the profile analysis ${ }^{18}$.

\section{Results}

Histological analysis of the liver in control animals was normal, and steatosis was observed in the liver of all alcoholic animal's group. Mean weight of all rats increased along the experiment but was significant higher in control rats than that in alcoholic rats $(\mathrm{p}<0.01)$ (Figure 2$)$.

The biomechanical study showed that only the strength at the yield point elongation increased in the alcoholic group $(1.94 \pm 0.92$ vs $2.54 \pm 0.79, \mathrm{p}<0.05)$ (Figure 1 , Table 1$)$. No correlation between the biomechanical variables and animal weight was observed in both groups (Table 2). No differences in the thickness of arterial tunicas (Figure 3, Table 3) and proportion of collagen (Table 4) were found. The pathologist observed no histological difference between two groups in any case.

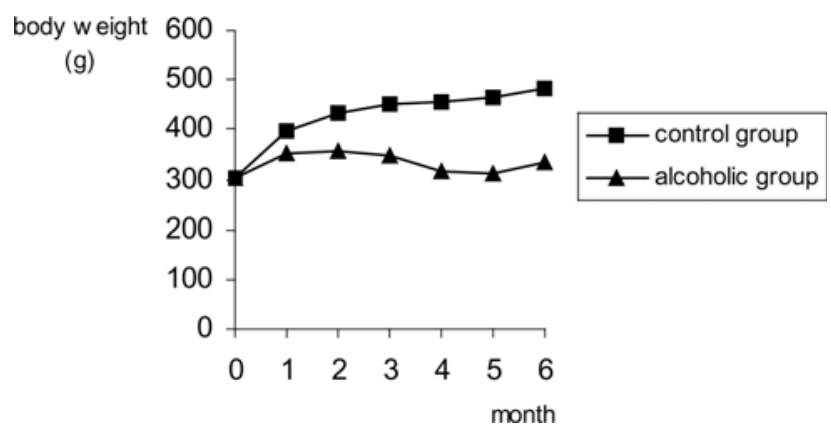

FIGURE 2 - Mean values of body weight (gram) during the study period.

TABLE 1 - Means, standard deviations, and statistical results of biomechanical variables in both groups.

\begin{tabular}{llll}
\hline Variable & Control & Alcoholic & Statistical result \\
\hline Failure load $(\mathrm{N})$ & $2.80 \pm 0.90$ & $2.48 \pm 0.96$ & $\mathrm{t}=1.01(\mathrm{p}>0.05)$ \\
Yield point $(\mathrm{N})$ & $2.01 \pm 1.12$ & $2.09 \pm 0.78$ & $\mathrm{t}=0.25(\mathrm{p}>0.05)$ \\
Failure elongation $(\mathrm{mm})$ & $3.42 \pm 0.99$ & $3.51 \pm 0.81$ & $\mathrm{t}=0.27(\mathrm{p}>0.05)$ \\
Yield point elongation $(\mathrm{mm})$ & $1.94 \pm 0.92$ & $2.54 \pm 0.79$ & $\mathrm{t}=2.05(\mathrm{p}<0.05)$ \\
Stiffness* $(\mathrm{N} / \mathrm{mm})$ & $0.80 \pm 0.41$ & $0.73 \pm 0.17$ & $\mathrm{z}=1.03(\mathrm{p}>0.05)$ \\
\hline
\end{tabular}

$\mathrm{N}=$ Newton; $\mathrm{mm}=$ millimeter

* median + interquartil semirange

TABLE 2 - Person's correlation coefficient between weights and variables studied in both groups.

\begin{tabular}{lll}
\hline Correlation with weigth & Control (p value) & Alcoholic (p value) \\
\hline Failure load & $-0.09(\mathrm{p}>0.05)$ & $0.12(\mathrm{p}>0.05)$ \\
Yield point & $-0.06(\mathrm{p}>0.05)$ & $0.16(\mathrm{p}>0.05)$ \\
Failure elongation & $0.11(\mathrm{p}>0.05)$ & $-0.31(\mathrm{p}>0.05)$ \\
Yield point elongation & $0.09(\mathrm{p}>0.05)$ & $-0.25(\mathrm{p}>0.05)$ \\
Stiffness* & $-0.14(\mathrm{p}>0.05)$ & $0.35(\mathrm{p}>0.05)$ \\
\hline
\end{tabular}

* Spearman's correlation coefficient

TABLE 3 - Means, standard deviations, and statistical results of thickness of the media and adventitia $(\mu)$ of the aorta in both groups.

\begin{tabular}{llll}
\hline Variable & Control & Alcoholic & Statistical result \\
\hline Media + adventitia & $197.948 \pm 63.261$ & $188.019 \pm 45.026$ & $\mathrm{t}=0.28(\mathrm{p}>0.05)$ \\
Media & $87.407 \pm 25.358$ & $95.841 \pm 42.241$ & $\mathrm{t}=0.38(\mathrm{p}>0.05)$ \\
Adventitia & $108.553 \pm 35.335$ & $91.258 \pm 16.693$ & $\mathrm{t}=0.99(\mathrm{p}>0.05)$ \\
\hline
\end{tabular}


TABLE 4 - Median, semi-amplitude, and statistical results of collagen proportion (\%) of the aortic media + adventitia in both groups.

\begin{tabular}{llll}
\hline Variable & Control & Alcoholic & Statistical result \\
\hline Collagen (\%) & $16.78 \pm 5.62$ & $7.52 \pm 2.07$ & $\mathrm{U}=7.00(\mathrm{p}>0.05)$ \\
\hline
\end{tabular}

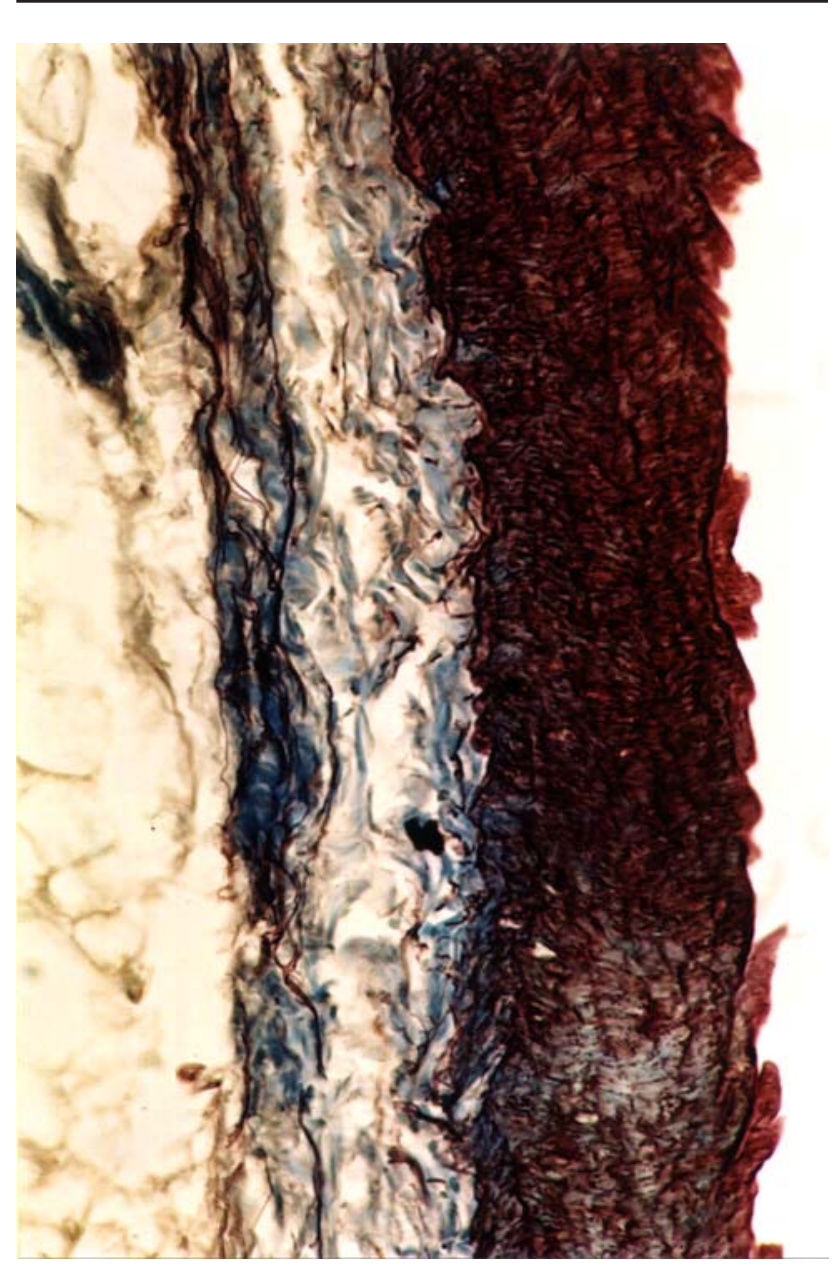

FIGURE 3 - Histomorphometry of control rat's aortic wall. The arrows indicate measurements. (Callejas Original magnification: 200x). Digital image obtained using IPWIN32 software.

\section{Discussion}

Alcoholism is associated with structural and functional alterations of blood vessels. Decreased thickness of the intima and media in the thoracic aorta was reported in histological and ultrastructural studies with rats submitted to chronic alcoholism ${ }^{19}$. Another study reported degeneration of the endothelial surface of myocardium capillaries in mice treated with $15 \%$ ethanol for 3 months ${ }^{13}$. Sarphie et al. ${ }^{20}$ showed that alcohol caused structural changes in hepatic sinusoids of rats. Vascular wall edema, perivascular fibrosis, vascular sclerosis, subendothelial humps, and vascular wall inflammation in intramyocardium coronary arteries of alcoholic patients were observed in another morphological study ${ }^{21}$. In the present study, no differences in the thickness of arterial tunicas and proportion of collagen were found, maybe because of variability which would demand for a greater sample size. Anyway, no detectable histological difference was observed between both groups by the pathologist.

Alcohol can exert direct actions on cerebral blood vessels. Altura et al. ${ }^{11}$ showed that alcohol caused vasospasm in intact cerebral arterioles and venules and in isolated cerebral arteries. The same authors described a canine coronary artery vasospasm in an in vitro study ${ }^{12}$. In the same study, they also demonstrated that acetaldehyde, which is the major metabolite of ethanol, produced relaxation in coronary basal tone. However, the bulk of the evidence suggests that ethanol increases coronary blood flow and decreases coronary vascular resistance ${ }^{8}$.

Authors did not find alterations in the anatomy, histology, histochemistry, and electronic microscopy of the arteries, veins, and capillaries of rats receiving liquid diet containing alcohol during one year ${ }^{14}$. Phillips ${ }^{22}$ observed that the endothelial cells of brain blood vessels in rats breathing continuous ethanol vapor during 3 weeks were normal, which is in accordance to the present study, with no histopathological alterations in the endothelium, collagen, and muscle fibers found in comparison to controls. Differences related to animal species, type of artery, and experimental model may explain the discrepancies found in literature. In the present study, the only biomechanical difference observed was related to the increase in yield point elongation in alcoholic group. In these words, the aortas of alcoholic group stretched more than controls, before irreversible changes occurrence. The highest aortic elongation capacity in alcoholic rats might be due to either lower collagen synthesis, increase in collagen lysis, or even higher elastin synthesis, which were not detectable in our microscopic studies. Santi ${ }^{18}$ observed an increase of nonoriented collagen fibers in the media, suggesting that alcohol interferes with collagen synthesis, and that the disorganized increase of these fibers triggers a vascular fibrosis process.

Biomechanical parameters in blood vessels are frequently used in the study about aneurism ${ }^{23}$, diabetes ${ }^{24,25}$, hypertension ${ }^{26}$, age a $^{27}$ drug action ${ }^{28,29,30}$, and exercise training ${ }^{31}$. Tensile testing reflects ultimately the stiffness, distensibility, elasticity and mechanical strength, of collagen and elastin in aortic samples ${ }^{25}$. The extracellular matrix (ECM) plays a critical role in the development, growth and biomechanical properties of virtually every organ. The wall of a vessel has a complex structure, and elastic properties of the wall are affected mainly by the interrelation of collagen and elastin ${ }^{30}$. The cross-links stabilize the collagen fibrils and provide distensibility, elasticity and mechanical strength to the blood vessels, but the excessive formation of cross-links leads to the deranged biomechanical properties of vessel tissue ${ }^{25}$.

Altered degradation of extracellular matrix (ECM) underlies vascular remodeling, a hallmark in the pathogenesis of another cardiovascular diseases including hypertension and aneurismal dilatation ${ }^{32}$. The molecular structure of collagen and elastin may alter the mecanical properties of the aortic wall and change the aortic susceptibility to hemodynamic injury. A primary increase in the extensibility implies a secondary fibroproliferative response of the aortic wall. The excess deposition or alterations in collagen and elastin lead to increased stiffness 
at small "stress" values, which in turn may increase the hemodynamic strain. Increased stiffness of the aorta may be of pathogenic significance in atherosclerosis ${ }^{26,28}$. It is impossible to rain any extrapolation of increased elongation of aorta predisposing to aneurysm formation or influencing systemic blood pressure levels.

The amount of aortic wall collagen and elastin was not substantially changed by alcohol in the present study, as determined by the histomorphometric study performed.

Further studies are necessary to unify eventual aortic elastin and collagen quality changes after alcohol addiction inducing biomechanical aortic properties alterations.

\section{Conclusion}

In conclusion, this study suggests that chronic alcoholism does not promote morphological alterations in rat abdominal aorta wall, but may increase its elongation, without modifying any other mechanical properties. Further analysis involving ultrastructural and biochemical evaluation of aortic wall components are necessary to explain these results.

\section{References}

1. O’brien, CP. Drug addiction and drug abuse. In: Goodman \& Gilman's: the pharmacologic basis of therapeutics. 9 ed. International Editon, McGraw-Hill, 1996, p.557-77.

2. Programa Álcool e Drogas (PAD) do Hospital Israelita Albert Einstein. Site Álcool e Drogas sem Distorção. Disponível em: www.einstein.br/alcooledrogas.

3. Almeida Filho N, Mari JJ, Coutinho E, França JF, Fernandes JG, Andreoli SB, Busnello ED. [Multi center study of psychiatric morbidity in Brazilian urban areas]. Estudo multicêntrico de morbidade psiquiátrica em áreas urbanas brasileiras (Brasília, São Paulo e Porto Alegre). Rev ABPAPAL. 1992; 14: 93-104.

4. Arnt R. Flagelo corporativo. Revista Exame 2001; ed.743, ano 35, n.13, 42-52.

5. Cotran RS, Kumar V, Robbins SL. Environmental and nutritional diseases. In:__. Robbins Pathologic Basis of Disease. 5 ed. Philadelphia:W. B. Saunders Company, 1994. Cap. 9, pp.379-430.

6. Palmer TN. The biochemistry of alcohol and alcohol abuse. Sci Prog Oxf. 1989;73: 1-15.

7. Silva JBG, Lisboa JAC, Freitas MRG, Nascimento OJM. [Morphological study of gastrocnemy muscle of C57BL10 mice submitted to chronic ingestion of ethanol.] Estudo morfológico no músculo gastrocnêmio de camundongos C57BL10 submetidos à ingestão prolongada de etanol. Arq Neuropsiquiatr. 1996; 54:2: 260-72.

8. Ahlawat SK, Siwach SB. Alcohol and coronary artery disease. Int J Cardiology 1994; 44: 157-62

9. Taraschi, T. F. and Rubin, E., Effects of ethanol on the chemical and structural properties of biologic membranes. Lab Invest 1985; 52: 120-131.

10. Rubin E, Rottenberg H. Ethanol-induced injury and adaptation in biological membranes. Fed Proc. 1982; 41: 2465-71.
11. Altura BM; Altura BT, Gebrewold A. Alcohol-induced spasms of cerebral blood vessels: relation to cerebrovascular accidents and sudden death. Science 1983; 220: 331-2.

12. Altura BM, Altura BT, Carella A. Ethanol produces coronary vasospasm: evidence for a direct action of ethanol on vascular muscle. Br J Pharmac. 1983; 78: 260-2.

13. Sohal RS, Burch GE. Effect of ethanol ingestion on the myocardial capillaris of mice. Cardiovasc Res. 1969; 3: 369-373.

14. Morvai V, Ungvary G. Morphological alterations due to long term alcohol intake in rats. Exp Pathol. 1987; 31: 153-160.

15. Yoshida WB, Müller, SS, Carvalho I., Fabreis VE, Naresse LE, Maffei FHA. Tensile strength and histological changes of abdominal aorta of malnourished rats. Cardiovasc Surg. 1995; 3: 437-39.

16. Carstedt CA, Nordin M. Biomechanics of tendons and ligaments. In: Nordin, M. Frankel, V.H. Basic biomechanics of the musculoskeletal system. 2.ed. Philadelphia Lea \& Febigen, 1989. pp.59-74.

17. Streiner DL, Norman GR. Biostatistics - the bare essentials. St. Louis, Mosby-Year Book, 1994, 260p.

18. Johnson RA, Wichern DW. Applied multivariate statistical analysis. Prentice Hall, New Jersey, 1992, 642p.

19. Santi FP. [Study of the thoracic aorta wall of rats (Rattus norvergicus) submitted to experimental chronic alcoholism.] Estudo da parede da aorta torácica de ratos (Rattus norvergicus) submetidos ao alcoolismo crônico experimental (tese). Botucatu, São Paulo State University; 1993.

20. Sarphie TG, Chronic alcohol feeding in liquid diet or in drinking water has similar effects on electron microscopic appearance of the hepatic sinusoid in the rat. Alcohol Clin Exp Res. 1996; 20: 973-9.

21. Factor M. Intramyocardial small-vessel disease in chronic alcoholism. Am Heart J. 1976; 92: 561-75.

22. Phillips, SC, Does alcohol-induced blood cell agglutination cause brain damage? J Neurol Sci. 1986; 72: p.43-8.

23. Vorp DA, Schiro, B Ehrlich, MP Juvonen, TS Ergin, MA, Griffith BP. Effect of aneurysm on the tensile strength and biomechanical behavior of the ascending thoracic aorta. Ann Thorac Surg. 2003; 75: 1210-4.

24. Zhao J, Lu X, Zuang F, Gregersen H. Biomechanical and morphometric properties of the arterial wall referenced to the zero-stress sate in experimental diabetes. Biorheology 2000; 37: 385-400.

25. Andreassen TT, Oxlund H. Changes in collagen and elastin of the rat aorta induced by experimental diabetes and food restriction. Acta Endocrinol. 987; 115: 338-44.

26. Mizutani K, Ikeda K, Kawai Y, Yamori Y. Biomechanical properties and chemical composition of the aorta in genetic hypertensive rats. Hypertens 1999; 17: 481-7.

27. Bruel A, Oxlund H. Changes in biomechanical properties, composition of collagen and elastin, and advanced glycation endproducts of the aorta in relation to age. Atherosclerosis 1996; 127: 155-65.

28. Bruel A, Oxlund H. Biosyntetic growth hormone changes the collagen and elastin contents and biomechanical properties of the rat aorta. Acta Endocrinol. 1991; 125: 49-57. 
29. Oxlund H, Andreassen TT, Junker P, Jensen BA, Lorenzen I. Effect of D-penicillamine on the mechanical properties of aorta, muscle tendon and skin in rats. Atherosclerosis 1984; 52: 243-52.

30. Oxlund H. Changes in the biomechanical properties of skin and aorta induced by corticotrophin treatment. Acta Endocrinol. 1980; 94: 132-7.
31. Matsuda M, Nosaka T, Sato M, Iijima J, Ohshima N, Fukushima H. Effects of exercise training on biochemical and biomechanical properties of rat aorta. Angiology. 1989; 40: 51-8.

32. Partridge CR; Sampson HW; Forough R. Long-term alcohol consumption increases matrix metalloproteinase-2 activity in rat. Life Sci. 1999; 65: 1395-402.

\section{Correspondence:}

Nereide Freire Cerqueira

Departamento de Cirurgia e Anestesiologia Veterinária

Faculdade de Medicina Veterinária e Zootecnia de Botucatu - UNESP

Distrito de Rubião Jr. - Caixa Postal 560

18618-000 Botucatu - SP Brazil

Tel: (5514)3811-6252

Fax:(5514)38116072

nereide@fmvz.unesp.br

nereidefc@hotmail.com
Conflict of interest: none Financial source: FUNDUNESP

Received: January 18, 2005

Review: February 21, 2005

Accepted: March 23, 2005

\section{How to cite this article:}

Cerqueira, NF, Yoshida, WB, Müller, SS, Sequeira, JL, Rodrigues, AC, Padovani, CR. Morphological and biomechanical study of abdominal aorta of rats submitted to experimental chronic alcoholism. Acta Cir Bras. [serial online] 2005 MayJune;20(3). Available from URL: http://www.scielo.br/acb

*Color figure available from http://www.scielo.br/acb 